Ethiopian Journal of Environmental Studies \& Management 10(1): 38 - 43, 2017.

ISSN:1998-0507

doi: http://dx.doi.org/10.4314/ejesm.v10i1.4

Submitted: September 27, 2016

Accepted: January 19, 2017

\title{
PROSPECTS AND CONSTRAINTS ON UTILIZATION OF Jatropha curcas SEEDS IN ANIMAL FEEDSTUFF
}

\author{
*ANNONGU, A.A., ${ }^{1}$ JOSEPH, J.K., ${ }^{2}$ SOLA-OJO, F.E., ${ }^{1}$ BADMOS, A.A., ${ }^{1}$ YUSUFF, A.T., ${ }^{1}$ \\ UDDIN, R.O., ${ }^{3}$ AHMED, 0., ${ }^{3}$ LAWAL, O.A. ${ }^{4}$ AND EDOH, J.H. \\ ${ }^{1}$ Unit of Nutritional Biochemistry and Toxicology, Department of Animal Production, \\ University of Ilorin, Nigeria \\ ${ }^{2}$ Department of Home Economics and Food Science, University of Ilorin, Nigeria \\ ${ }^{3}$ Department of Crop Protection, University of Ilorin, Nigeria \\ ${ }^{4}$ ITAD Ltd, Hove, UK
}

\begin{abstract}
Combined physical, chemical and biochemical methods were used to process virgin seed meal of Jatropha curcas L. into treated Jatropha Seed Meal (JSM). Graded levels (0, 5, 10, 15, 20 and 25\%) JSM treated by the various methods was included in the test diets which were fed ad libitum to 360 albino rats for a month in a single factor design trial. The results revealed that feed intake was numerically highest $(p>0.05)$ for the rats on the $5 \%$ treated JSM diet, while feed efficiency was highest $(p>0.05)$ for those on the $10 \%$ treated JSM diets. Weight gain was significantly highest $(p<0.05)$ for the rats on 10 and $15 \%$ treated JSM diets. Lowest survival rate (17\%) was observed on treated JSM diet processed by boiling, roasting followed by fermenting. Biochemical indices measured on treated JSM based diets were comparable with those obtained on the conventional diet $(p>0.05)$ except for blood cholesterol level ( $p<$ $0.05)$ which was elevated with increasing treated JSM in diets. There were also no significant differences recorded on AST and ALP activities ( $p>0.05$ ) between the treatments. Haematological indices investigated including $P C V, R B C, H b$ were insignificantly influenced by the 5\% dietary treated JSM compared with the control diet $(p>0.05)$ and there was nonsignificant effect of the dietary treatment on the WBC differential counts of lymphocytes, eosinophils, monocytes and neutrophils. It was established in this study that inclusion of 5\% treated JSM in diets had no detrimental effect on albino rats. Further researches are in progress to investigate inclusion of the treated JSM in diets at levels higher than the 5\% used in this study.
\end{abstract}

Key Words: JSM, Cockerels, Performance, Biochemical and haematological parameters

\section{Introduction}

Man has been cultivating plants for centuries as sources of food, medicine, timber and for their oil. Some plants like alfalfa are grown solely for use by animals as feedstuff while oil-seed bearing plants like groundnuts, soybeans, maize, sesame usually have their oil extracted and the protein-rich residues are used for feeding farm animals. The production of oil plants

*Corresponding Author: Annongu, A.A.

Email: azorann@yahoo.com 
takes third place in world agricultural production in terms of value after carbohydrate and beverage (tea, coffee) plant and more than $90 \%$ of the oil plants are produced in the tropics and subtropics (Dari, 2009). Jatropha curcas plant, the seeds of which are used in this study is a multi-purpose oil bearing shrub cultivated mainly for the production of seeds as their oil content is $55-60 \%$ of the seed. A seed yield of about 5 tons per year from one hectare plantation has been reported (Raina and Gaikwad, 1987; Makkar and Becker, 1997, Dari, 2009), and this can produce two tons of oil and one tone of protein-rich seed meal. The oil is a source of fuel for diesel engines, and an indication of the potential J.curcas as a renewable energy source. The oil from J.curcas is also widely used for skin diseases and to alleviate pains such as rheumatism. The oil, besides its biodiesel and medicinal uses, is used for manufacture of soap, cosmetics, lubrication and bio-pesticides. The seed meal or cake left after oil extraction can be used as an organic fertilizer, but is mostly discarded as waste as it is considered unsuitable as animal feed due to its high toxicity.

Earlier studies (Adam, 1974; Chikpah and Demuyakor, 2013) on the toxicity of $J$. curcas reported that a diet containing 40 and $50 \%$ raw jatropha seed meal led to high mortality (67\%) of mice within 3-16 days, while at inclusion levels ranging from $5-20 \%$ of the virgin seed meal in diets, the mortality rate was reduced, suggesting a dose response. Liberalino et al. (1988) similarly reported that rats given a diet containing $37 \%$ of unprocessed decorticated Jatropha seeds died within 2-3 days after ingestion and a the mortality was $100 \%$. Studies on larger nimals (sheep, goats, calves, poultry) have also shown that chicks fed a diet containing $J$. curcas seeds alone or in diet suffered adverse effects. Adam and Magzoub (1975) noted that goats fed $1 \mathrm{~g}$ seeds $/ \mathrm{kg}$ live weight/day died within 2-9 days while $J$. curcas toxicity to calves at single doses from $0.025 \mathrm{~g} / \mathrm{kg}$ live weight/day and above resulted to death within 14 days of intake. Previous investigations describing poisoning in humans by accidental ingestion of $J$. curcas seed (Lippmann, 1913; Abdu-Aguye et al., 1986; Joubert et al. 1984; Mampane et al., 1987; Makkar and Becker 1999) noted clinical signs like giddiness, vomiting and diarrhea. The chemical composition of $J$. curcas seeds revealed that the seed is rich in lipid, protein, with less mineral matter, but the presence of the noxious phytochemicals in the seed could limit the availability and/or utilization of the nutrients in the fed animals. Some examples of anti-nutritional factors in seeds from the toxic variety include phorbol esters (equivalent of phorbol-12-myristate 13-acetate), lectins which elicits haemagglutination of red blood cell, protease (trypsin) inhibitors, saponins, anti-metals like phytates (Makkar and Becker, 1999). The objectives of this study were to attempt the detoxification of $J$. curcas seeds obtained from Ilorin, Kwara state of Nigeria and to evaluate the nutritional adequacy of the detoxified $J$. curcas seed meal at graded levels in livestock diets using albino rats as experimental animal models.

\section{Materials and Methods}

Ripe fruits of $J$. curcas from a plantation in Ilorin, Kwara state of Nigeria were worked to the seeds. Split seeds of $10 \mathrm{~kg}$ were boiled and subjected to fermentation under carbon dioxide environment as described by Annongu et 
al. (1996). Boiling and lactic fermentation treatments were followed by soaking the dough in equal volumes of hexane and ethanol for one day in order to extract the lipo-soluble chemical compounds. After oil extraction, the coarse dough was milled to the required particle size before incorporation in diet mixtures. Six diets of similar protein and energy contents were formulated as presented on Table 1.

Table 1: Composition of the experimental diets on as fed basis ( $\mathrm{g} / \mathrm{kg}$ diet)

\begin{tabular}{lllllll}
\hline Diets & 1 & 2 & 3 & 4 & 5 & 6 \\
\hline Ingredients & & & & & & \\
\hline Corn starch & 516.00 & 516.00 & 516.00 & 516.00 & 516.00 & 516.00 \\
Soybeanmeal & 250.00 & 200.00 & 150.00 & 100.00 & 50.00 & 0.00 \\
TJSM & 0.00 & 50.00 & 100.00 & 150.00 & 200.00 & 250.00 \\
Sucrose & 100.00 & 100.00 & 100.00 & 100.00 & 100.00 & 100.00 \\
Cellulose & 40.00 & 40.00 & 40.00 & 40.00 & 40.00 & 40.00 \\
DLmethionine & 4.00 & 4.00 & 4.00 & 4.00 & 4.00 & 4.00 \\
Premix & 50.00 & 50.00 & 50.00 & 50.00 & 50.00 & 50.00 \\
Total & 1000.00 & 1000.00 & 1000.00 & 1000.00 & 1000.00 & 1000.00 \\
\hline
\end{tabular}

Treated Jatropha seed meal (JSM) was included in test diets at the expense of soybean meal at graded levels of $5,10,15$, 20 and $25 \%$ corresponding to $50,100,150$, 200 and $250 \mathrm{~g} / \mathrm{kg}$ diet for diets $2,3,4,5$ and 6 respectively while diet 1 was the reference (control) diet containing maizesoybeans as basic ingredients. 72-Albino rats (age 3-weeks old) of equal sexes were distributed at random to the six dietary treatments. A diet was replicated twice with six rats per replicate and the design of the experiment followed a one-way classification. Rats were placed in cages designed for the purpose and fed the experimental diets ad libitum during the 21-day feeding trial period. As the experiment lasted, data were collected on dietary performance characteristics. At the end of the feeding trial, one rat per replicate [on the treatments that contained complete number of surviving rats i.e diets 2-4 ] was taken and sacrificed by decapitation for the evisceration of organs (heart, lungs, liver, intestines) for carcass studies of relative organ weights (ROW).

\section{Chemical Analyses}

Quantitative determination of some phytochemicals in native JSM and in diets containing treated JSM was carried out for tannins as described by Joslyn (1970) and Adegunwa et al. (2011), Phytates according to wheeler and Ferrel (1971) and Ramadan (2012), cyanides and phorbolesters following the procedures of AOAC (1990). Saponins were determined as outlined by Hudson and El-Difrawi (1979) and Ukpabi and Ukpabi (2003).

\section{Statistical Analysis}

Data on analysis of the phytochemicals in the virgin JSM and those in the processed JSM in diets were subjected to descriptive statistics while data on the performance characteristics and relative organ weights were analyzed by analysis of variance (ANOVA) following the model for a single factor design (Steel and Torrie, 1990).

\section{Results and Discussion}

Data on the quantitative determination of the phytochemicals in raw JSM are shown on Table 2. Native JSM from Ilorin 
contains high levels of the phytotoxins, phorbol esters $(2.79 \mathrm{mg} / \mathrm{g}$ sample), haemagglutinins $\quad(102 \mathrm{mg} / \mathrm{g} 0, \quad$ saponins (2.60\%), Protease (trypsin) inhibitors $(21.3 \mathrm{mg} / \mathrm{g})$, phytates $(9.40 \%)$, total phenol content of $0.36 \%$ and negligible tannin content of $0.04 \%$. Analyses of residues of these chemical compounds in the treated JSM diets (Table 3) still appeared high especially for phytates and cyanide contents. High levels of these antinutritional factors could predispose the nutrients in the seed meal to be unavailable for utilization in the fed animals or may have untoward effects on nutrition especially in monogastric animals.

Table 4 presents data on dietary performance of albino rats fed graded levels of treated JSM in diets. There were no significant differences in average feed consumption and efficiency in the surviving groups of rats offered up to $150 \mathrm{~g}$ processed JSM $/ \mathrm{kg}$ diet (diets 2, $3 \& 4$ ) and that on the control diet $(\mathrm{p}>0.05)$ in comparison with the control. Body weight gain of rats on diets 2-4 increased in response to the increase in treated JSM in the diets $(\mathrm{p}<0.05)$ relative to the control diet. In addition, there was no mortality on the three diets (2-4) just like the control group with a $100 \%$ survival rate and efficiency of feed utilization between these diets and the reference diet was insignificant $(p>0.05)$. The performance of rat maintained on the diets 2 to 4 (50 to $150 \mathrm{~g} \mathrm{JSM} / \mathrm{kg}$ feed) compared with the control could probably be due to the improvement in the nutritional value of the processed JSM in the diets 2-4 at these levels of inclusion acting in concert with the increment in the nutrient(s) content especially protein. Previous studies (Makkar and Becker 1999) showed that $J$. curcas seeds contain between 56-60\% crude protein. High protein content of the treated JSM at $5-15 \mathrm{~kg}$ inclusion might have caused increased weight gain on the diets in question. On the other hand, rats ingesting diets 5 and 6 containing $20-$ $25 \%$ treated JSM corresponding to 200$250 \mathrm{~g} / \mathrm{kg}$ test feedstuff all died within one week in the course of the 3 -weeks feeding period, indicating that inclusion of treated JSM at levels above $15 \%$ is not tolerated by the monogastric (rat). The nonacceptability of JSM, though treated, could be attributable to the cumulative effects of $J$. curcas seeds residual phytotoxins which persisted despite processing. Analyses of diets containing the treated JSM for the residual phytotoxins presented high levels of cyanides, phytates, saponins (Table 3). Relative organ weights (ROW) data (Table 5) showed that the heart, lungs, liver weights on diets 2-4 developed concomitantly with increasing dietary treated JSM. This development was in positive response to the improvement in the nutritional value of the diets.

In conclusion, processing JSM by the methods used and including at $15 \%$ $(150 \mathrm{~g} / \mathrm{kg}$ diet $)$ has no detrimental effects on the performance and organ developments of albino rats, but levels beyond $15 \%$ could result to heavy mortality. 
Table 2: Analyzed Phytochemical Contents in Virgin Jatropha Seed Meal

\begin{tabular}{ll}
\hline Phytotoxin & Concentration \\
\hline Phorbolesters & $2.79 \mathrm{mg} / \mathrm{g}$ \\
Total phenols & $0,36 \%$ \\
Tannins & $0,04 \%$ \\
Phytates & $9.40 \%$ \\
Saponins & $2.60 \%$ \\
Protease (trypsin) inhibitors & $21.3 \mathrm{mg} / \mathrm{g}$ \\
Haemagglutinins & $102 \mathrm{mg} / \mathrm{g}$ \\
\hline
\end{tabular}

Table 3: Analyzed Residual Phytotoxins Concentration in Treated Dietary JSM

\begin{tabular}{lllllll}
\hline Diets & 1 & 2 & 3 & 4 & 5 & 6 \\
\hline Phytochemical & & & & & & \\
\hline Cyanides,ppm & 0.00 & 1.01 & 1.10 & 1.12 & 1.15 & 1.20 \\
Saponins,ppm & 0.00 & 0.70 & 0.75 & 0.82 & 0.85 & 0.90 \\
Phytic acid,\% & 0.00 & 5.15 & 5.36 & 6.18 & 6.80 & 7.83 \\
Tannin, g/dm & 0.00 & 0.05 & 0.05 & 0.05 & 0.06 & 0.06 \\
\hline
\end{tabular}

Table 4: Dietary Performance of Albino Rats Fed Graded Levels of Treated Dietary JSM

\begin{tabular}{llllllll}
\hline Diets & 1 & 2 & 3 & 4 & 5 & 6 & SEM \\
\hline Parameters & & & & & & & \\
\hline Mean feed intake (g/r/d) & 21.53 & 24.43 & 21.11 & $21.10 \mathrm{NS}$ & - & - & 1.6 \\
Mean weight gain (g/r/d) & $15.00^{\mathrm{a}}$ & $15.40^{\mathrm{a}}$ & $17.10^{\mathrm{b}}$ & $17.30^{\mathrm{b}^{*}}$ & - & - & 1.17 \\
Feed efficiency (F/G) & 1.40 & 1.58 & 1.20 & $1.22 \mathrm{NS}$ & - & - & 0.17 \\
Survival rate (\%) & 100.00 & 100.00 & 100.00 & 100.00 & - & - & - \\
\hline
\end{tabular}

a-b mean values in the row not sharing common superscripts differed significantly $(\mathrm{p}<0.05)$

NS, no significant difference $(\mathrm{p}>0.05)$

Table 5: Relative Organ Weights (ROW) of Rats Fed Graded Levels of Processed Dietary JSM

\begin{tabular}{llllllll}
\hline Diets & 1 & 2 & 3 & 4 & 5 & 6 & SEM \\
\hline ROW & & & & & & & \\
\hline Heart & $0.80^{\mathrm{a}}$ & $0.85^{\mathrm{c}}$ & $0.82^{\mathrm{b}}$ & $0.84^{\mathrm{c}}$ & - & - & 0.02 \\
Lungs & $2.47^{\mathrm{a}}$ & $2.63^{\mathrm{b}}$ & $2.55^{\mathrm{b}}$ & $2.40^{\mathrm{a}}$ & - & - & 0.09 \\
Intestines & $4.78^{\mathrm{b}}$ & $4.76^{\mathrm{b}}$ & $4.82^{\mathrm{c}}$ & $4.69^{\mathrm{a}}$ & - & - & 0.05 \\
Liver & $0.92^{\mathrm{a}}$ & $0.92^{\mathrm{a}}$ & $1.00^{\mathrm{b}}$ & $1.01^{\mathrm{b}}$ & - & - & 0.04 \\
\hline
\end{tabular}

$a-b-c$ treatment mean values in rows not sharing common letters are significantly different $(p<0.05)$

\section{References}

Abdu-Aguye, I.A., Sannusi, R.A., AlafiyaTayo and S.R. Bhusnurmath (1986). Acute Toxicity studies with Jatropha curcas. Human Toxicol. 5, 269-274.

Adam, S.E.I. (1974). Toxic effects of Jatropha curcas in mice. Toxicol., 2, 67-76.
Adam, S.E.I. and Maghzoub, M. (1975). Toxicity of Jatropha curcas for goats. Toxicol., 4: 347-354.

Adegunwa, M.O., Alamu, E.O. and Omitogun, L.A. (2011). Effect of processing on nutritional contents of yam and cocoyam tubers. J. Appl. Biosc., 46: 3086- 3092

Annongu, A.A., terMeulen, U., Atteh, J.O. and Apata, D.F.

(1996). 
Toxikologische beurteilung von native und industriellfermentiertem Schibutter-Oelkuchenfuer die Futterung von Broilern. Arch. Gefluegelkunde, 60: 221-226.

A.O.A.C. (1990). Official Methods of Analysis, $15^{\text {th }}$ Edn., Association of Official Analytical Chemists, Washington DC., USA.

Chikpah, S.K. and Demuyakor B. (2013). Evaluation of nutritional and antinutritional composition of meals of Jatropha curcas seeds/kernels obtained from four different agroclimatic areas of Ghana. Agricultural Advances, Vol.2, no 1 Jan. 2013.

Dari, L. (2009). Effect of Different Solvent on the Extraction of Soya Bean Oil. M. Sc. Thesis. University of Science and Technology Kwame Nkrumah, Ghana; 2009.

Hudson and El-Difrawi (1979). The method for sapogenins determination in seeds of Lupine spp. and Jatropha plant. Food Chem., 3: 181-186.

Joslyn, M.A. (1970). In: Methods in Food Analysis. Academic Press, London, pp: 845.

Joubert, P.H., Brown, J.M.M., Hay, I.T. and Sebata, P.D.B. (1984). Acute poisoning with Jatropha curcas purging nut tree in children. S. Afric. Med. J., 65, 729-730.

Liberalino, A.A.A., Bambirra, E.A., Moraes-Santos, T. and Viera, E.C. (1988). Jatropha curcas L. seeds: Chemical analysis and toxicity. Arq. Biol. Technol., 31, 539-550.

Lippmann, A. (1913). ZweiFaelle von schwerervergiftungdurch

Curcasnuesse. MedizinischeKlinik No. 13: 500-501.

Makkar, H.P.S. and Becker, K. (1997). Potential of Jatropha seed meal as a protein supplement to livestock feed and constraints to its utilization. Proceedings of Jatropha 97: International Symposium on Biofuel and Industrial Products from Jatropha curcas and other tropical oil seed plant, 23-27 Feb. 1997, Managua, Nicaragua, Mexico.

Makkar, H.P.S. and Becker K. (1999a). Edible provenances of Jatropha curcas from Quit RPP state of Mexico and effect of roasting on anti-nutrients and toxic factors in seeds. J. Agric. Food Chem., 45: 3152-3157.

Makkar, H.P.S. and Becker, K. (1999b). Plant toxins and detoxification methods to improve feed quality of tropical seeds. Asian-Aust. J. Anim. Sci., 12: 467-480.

Raina, A.K. and Gaikwad, B.R. (1987). Chemobotany of Jatropha species in India and further characterization of Curcas oil, 1. Oil Tech. India, 19, 8185.

Ramadan, E.A. (2012). Effect of Processing and Cooking Methods on the Chemical Composition, Sugars and Phytic Acid of Soybeans. Food and Pub. Health. 2(1): 11-15. DOI: 10.5923/j.fph.20120201.03

Steel, R.G.D. and Torrie, J.H. (1990). Principles and Procedures of Statistics. A Biometrical Approach, $2^{\text {nd }}$ Edn., Mcgraw-Hill Book Company, New York.

Ukpabi, U.H. and Ukpabi, U.J. (2013). Potential of seeds of Napoleona imperialis ( $\mathrm{p}$. beauv) as a source of haemolytic saponin and feed ingredients. Livestock Res. for Rural Dev. 15 (12) 2003.

Wheeler, E.L. and Ferrel, R.E. (1971). A method for phytic acid determination in wheat fractions. Cereal Chem. 48: 312-320. 